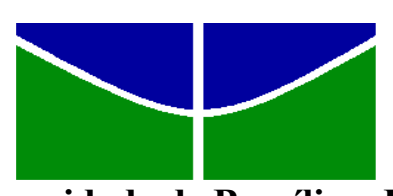

Universidade de Brasília - UnB

Instituto de Ciências Humanas - IH

Departamento de Geografia

Curso de Bacharelado em Geografia

\title{
Análise espacial do mercado de música do Distrito Federal
}

Aluna: Nina Puglia Oliveira - 05/37179

Orientador: Neio Lúcio Oliveira Campos

Brasília - DF

2009 
Instituto de Ciências Humanas - IH

Departamento de Geografia

Curso de Bacharelado em Geografia

\title{
Análise espacial do mercado de música do Distrito Federal
}

\author{
Nina Puglia Oliveira \\ Monografia de Prática e Pesquisa de Campo em Geografia II, apresentada ao \\ Departamento de Geografia do Instituto de Ciências Humanas da Universidade de \\ Brasília como parte dos requisitos para a obtenção do grau de Bacharel em Geografia.
}

Banca Examinadora:

Orientador: Prof. Dr. Neio Lúcio Oliveira Campos

Prof. Me. Gilberto Oliveira Júnior

Prof $^{\mathrm{a}}$ Ma. Rosângela Viana Vieira Néri

Brasília/DF, 6 de julho de 2009 


\section{Agradecimentos}

Primeiramente, aos meus pais, Júnia e Orlando, que sempre me apoiaram em minhas escolhas;

À Adélia Monti e à doutora Karina Oliveira, porque os seus trabalhos tornaram a minha caminhada muito menos árdua;

Ao Fred, que me convidou para fazer parte da sua equipe de pesquisa e que colaborou imensamente para a realização deste trabalho;

Aos meus amigos Leo Krieger e Alessandro Moura, excelentes músicos, que atenderam prontamente ao meu pedido para testar o questionário da pesquisa, e aos demais músicos que colaboraram com esta;

Aos meus fiéis amigos Aline, Seabra, Renato, Isa e Bia, a meu irmão, Tito, e a meus queridos primos Bernardo, Bianca e Marco, por acreditarem no meu potencial e terem tido a maior paciência comigo em todo o processo de elaboração deste trabalho;

Ao Bruno, pela ajuda e convivência durante o cursinho pré-vestibular;

Ao professor Neio Lúcio Oliveira Campos, pela orientação, paciência e compreensão durante o andamento desta monografia.

A todos vocês o meu mais profundo e sincero Muito Obrigada! 
RESUMO: A cidade de Brasília foi planejada para ser a capital do Brasil e, como tal, o centro das decisões políticas do País. Atualmente, o que se vê é que tanto Brasília - que, de fato, atende a esse objetivo inicial - quanto todo o Distrito Federal constituem um espaço urbano bem caracterizado. Ao contrário do que se poderia imaginar, a capital federal parece não se inserir em algumas das principais redes que compõem o espaço brasileiro. Um dos casos mais marcantes diz respeito ao mercado cultural. Este trabalho não pretende apenas traçar um perfil econômico da produção cultural: a intenção é oferecer condições para a compreensão do impacto que a produção de bens e serviços culturais tem sobre o espaço. Para tanto, é preciso tecer uma série de reflexões acerca de como a Geografia pode contribuir para o estudo dos impactos e sobre o peso que a cultura tem sobre a economia.

Palavras-chave: Brasília; espaço; mercado cultural; impactos culturais; polos de crescimento. 


\section{LISTA DE FIGURAS}

Figura 1 - Mapa das RAs do DF .......................................................................... 6

Figura 2 - Mapa da RA I - Brasília ............................................................... 8 


\section{LISTA DE SIGLAS}

Apam - Associação de Pais, Alunos e Mestres

CEP - Centro de Educação Profissional

DF - Distrito Federal

EMB - Escola de Música de Brasília

FAC - Fundo de Apoio à Cultura

IBGE - Instituto Brasileiro de Geografia e Estatística

IdA - Instituto de Artes

IDH - Índice de Desenvolvimento Humano

LSIE - Laboratório de Sistemas de Informações Espaciais

MUS/UnB - Departamento de Música da Universidade de Brasília

Proep - Programa de Expansão da Educação Profissional

RA - Região Administrativa

RA I - Brasília

UnB - Universidade de Brasília 


\section{SUMÁRIO}

Resumo

Lista de figuras

Lista de siglas

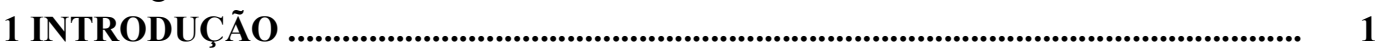

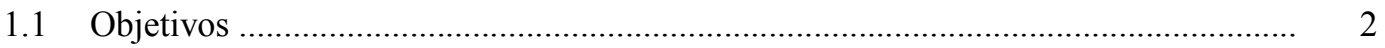

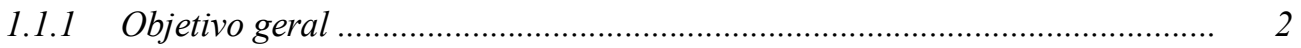

1.1.2 Objetivos especificos .......................................................................... 2

1.2 Problema de Pesquisa .......................................................................................... 2

1.3 Aspectos Metodológicos ....................................................................................... 4

1.3.1 Caracterização da área de estudo ................................................................... 6

2 APROXIMANDO MERCADO CULTURAL E ESPAÇO: ASPECTOS 9

TEÓRICOS ..........................................................................................................................................

$2.1 \quad$ A Arte e o Mercado Cultural n................................................................... 9

2.2 Mercado Cultural e Espaço ............................................................................ 15

3 PRIMEIRA FASE DA CADEIA PRODUTIVA DA MÚSICA NA RA I - 21

BRASÍLIA .................................................................................................................................

3.1 Centro de Educação Profissional - Escola de Música de Brasília (CEP-EMB) ............. 21

3.2 Escola de Choro Raphael Rabello................................................................................... 23

3.3 Departamento de Música da Universidade de Brasília (MUS/UnB) .......................... 24

4 RESULTADOS DA PESQUISA QUALITATIVA ............................................................ 25

5 PROPOSTA PARA DINAMIZAR A CADEIA PRODUTIVA DA MÚSICA NO 29

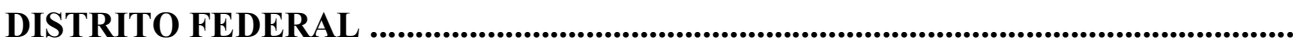

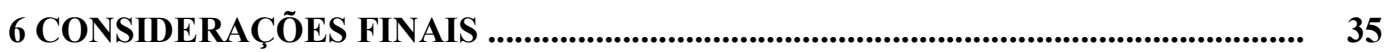

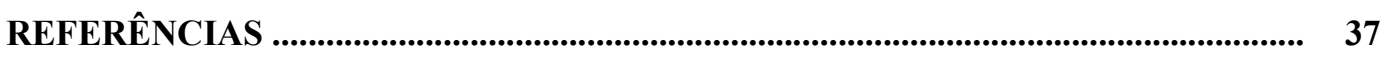

APÊNDICE A - Modelo de Questionário da Pesquisa Qualitativa ................................. 38

APÊNDICE B - Principais Escolas de Música e Locais de Show Apontados pela 42 Pesquisa Qualitativa 


\section{INTRODUÇÃO}

O Plano Piloto de Brasília, compreendido pela Região Administrativa I (RA I) do Distrito Federal (DF), foi planejado para ser a capital do Brasil e, como tal, o centro das decisões políticas do país. Atualmente, o que se vê é que tanto Brasília - que, de fato, atende a esse objetivo inicial - quanto todo o DF constituem um espaço urbano bem caracterizado.

Diversos fatores contribuem para que uma cidade importante seja um polo de atração de redes e fluxos dos mais variados elementos. Esse fenômeno, embora não seja exatamente uma regra, é observado em diversas cidades do Brasil e do mundo e é um dos fatores que influenciam o grau de importância de uma cidade.

Ao contrário do que se poderia imaginar, a capital federal parece não se inserir em algumas das principais redes que compõem o espaço brasileiro. Um dos casos mais marcantes diz respeito ao mercado cultural.

Álvarez (2003) explica que vários encontros internacionais que discutem a importância da indústria cultural para a economia defendem a necessidade de se dispor de "informações sistemáticas e confiáveis sobre o perfil das indústrias culturais, seu peso na economia, no número de empregos e na produção, distribuição e consumo de bens culturais, que não podem ser tratados como uma simples mercadoria” (p. 215).

Nesse sentido, o presente trabalho está estruturado da seguinte forma: um capítulo de problematização e de diretrizes metodológicas; um capítulo que apresenta uma revisão bibliográfica das características estruturais da cadeia produtiva da indústria cultural e dos conceitos geográficos que a embasam, formando o corpo teórico do trabalho; um capítulo no qual são apresentados os resultados da pesquisa e, por último, alguns indicadores que pretendem levar às possíveis respostas do problema de pesquisa. Não se trata, porém, apenas de traçar um perfil econômico da produção cultural. É necessário compreender o impacto que a produção de bens e serviços culturais tem sobre o espaço. Para isso, é preciso atentar para uma série de reflexões acerca de como a Geografia pode contribuir para o estudo dos impactos e do peso que a cultura tem sobre a economia.

É esse o caminho que se pretende traçar nesta pesquisa. Um caminho que leve não somente a respostas para as problemáticas que venham a surgir, mas que provoque, 
também, muitas indagações sobre o papel da Geografia como ciência e sobre como aplicar devidamente as propostas que ela pode trazer.

\subsection{Objetivos}

\subsubsection{Objetivo geral}

Investigar as condições de Brasília para impulsionar o crescimento na indústria cultural musical para, assim, se tornar um polo de crescimento no setor.

\subsubsection{Objetivos específicos}

1 - Analisar, em termos espaciais, a situação corrente do mercado cultural musical de Brasília, identificando seus problemas e suas potencialidades;

2 - Identificadas as potencialidades, investigar qual(ais) dela(s) se mostra(m) capaz(es) de se constituir como força motriz para impulsionar o desenvolvimento do mercado local;

3 - Se possível, propor estratégias para desenvolver o mercado cultural brasiliense, para inserir a cidade nas redes do mercado nacional - ou potencializar a sua inserção - e, consequentemente, para torná-lo um polo regional do setor.

\subsection{Problema de Pesquisa}

O ser humano é um ser social e, nessa condição, necessita de todas as formas de expressão artística e as produz e as aprecia. Seria inevitável, então, que, ao longo do desenvolvimento capitalista, a produção artística fosse incorporada à lógica de mercado, transformando a arte em um produto comercializável - e esse é o objeto de estudo deste trabalho.

Não se trata de discutir o conceito de arte, nem, tampouco, de julgar a qualidade da arte produzida como bem de consumo. O que será considerado aqui é o conceito de arte como elemento do espaço geográfico. 
O fato é que o mercado cultural é, hoje, um dos segmentos mais rentáveis da economia. Segundo Brant (2004), sua importância não é apenas econômica, mas também apresenta uma enorme capacidade de desenvolvimento humano e social. Ele tem características semelhantes às dos outros setores do mercado e é considerado pelos órgãos federais especializados um importante setor da economia brasileira. Explorá-lo e desenvolvê-lo em nível regional e/ou nacional são ações que dependem de diversos fatores.

No caso da música - foco principal desta pesquisa -, tanto no âmbito da produção como no do consumo, existe uma "cadeia produtiva". A formação de músicos e a existência de locais para a realização de espetáculos, de empresas de produção de eventos e artistas, de estúdios de gravação e de órgãos financiadores públicos ou privados podem ser citadas como exemplos de algumas das etapas que configuram o mercado cultural musical. Assim sendo, torna-se evidente a necessidade de investigar esse fenômeno com um olhar geográfico, pois esse é, claramente, um fenômeno espacial que traz benefícios culturais, sociais e econômicos para os agentes que dele participam.

Entender a dinâmica dessa "cadeia produtiva" do segmento musical torna possível encontrar os caminhos que levam ao desenvolvimento do setor. A partir de uma análise das características e do funcionamento desse mercado, este trabalho se propõe a estudar as particularidades de Brasília e sua relação com o mercado nacional.

A princípio, o que parece é que a capital federal, mesmo com algumas potencialidades evidentes, tais como escolas de música reconhecidas nacionalmente, estúdios bem equipados de gravação de discos e uma população que demanda consumo cultural, entre outras, ainda não conseguiu constituir um mercado musical local e talvez em consequência disso - não se consolidou na escala nacional por não conseguir inserir-se no circuito principal do respectivo mercado. Portanto, busca-se conhecer as possíveis causas e evidenciar as possíveis soluções para o problema. 


\subsection{Aspectos Metodológicos}

Do ponto de vista espacial, um elemento, qualquer que seja, não pode ser analisado isoladamente. De acordo com Santos (1985), os elementos espaciais são também variáveis. Tal variabilidade, porém, é inerente ao elemento em si. Ela se dá a partir do valor do elemento e da sua relação com outros elementos em determinado contexto, ou seja, em um momento histórico e em determinado lugar. Este possui características próprias que advêm da "valorização específica (ligada ao lugar) de cada variável". Além disso, "cada lugar atribui a cada elemento constituinte do espaço um valor particular" (p. 10). Dessa forma, todo e qualquer produto das firmas - que são elementos fundamentais do espaço - é elemento e variável do espaço. Assim sendo, o planejamento e a observação acurada das transformações espaciais podem ser as peçaschave para a constituição de uma cadeia produtiva exitosa no ramo da música.

O primeiro passo de uma análise espacial eficiente é a definição de um recorte espacial adequado ao estudo e a identificação dos elementos que este apresenta. Definidas as atividades consideradas partes integrantes do setor cultural de maneira geral - pois elas é que serão os elementos do espaço -, é preciso identificar quais dessas atividades contemplam o recorte espacial deste estudo, ou seja, a cadeia produtiva do ramo da música. Por isso, a base metodológica deste trabalho será calcada na sistematização da cadeia produtiva do setor cultural apresentada por Tolila, presente na seção 2.1.

O enfoque será sobre a primeira fase: a criação. Sem os compositores e sem músicos para a execução das composições, não há como estabelecer sequer a primeira fase da cadeia produtiva.

Feito isso, será realizada uma análise de como se configura esse mercado no DF e a dinâmica do seu sistema produtivo sob a ótica espacial, vista na seção anterior. A opção metodológica adotada para este trabalho foi a pesquisa qualitativa porque esta visa à obtenção de dados descritivos no contato direto com o(s) objeto(s) de estudo e usa a perspectiva dele(s) para entender o fenômeno estudado. Em outras palavras, "compreende um conjunto de diferentes técnicas interpretativas que visam a descrever e a decodificar os componentes de um sistema complexo de significados" (Neves, 1996, p.1). Essa escolha se deveu ao fato de a pesquisa qualitativa não impedir que o(a) pesquisador(a) se utilize da lógica do empirismo científico. Ela permite que ele(a) embase cientificamente fenômenos que não seguem, necessariamente, uma lógica ou 
um padrão de realização. Como explicita o autor, os pesquisadores que optam pelo método qualitativo "[...] buscam visualizar o contexto e, se possível, ter uma integração empática com o processo objeto de estudo que implique melhor compreensão do fenômeno" (p. 2).

Para tanto, serão selecionados alguns músicos de Brasília para o preenchimento de um questionário de pesquisa qualitativa, a fim de coletar as informações necessárias para caracterizar a cadeia produtiva da música na capital. Esses músicos selecionados são também professores de música de diversas escolas da cidade, pois são eles os principais responsáveis pela formação de músicos e, portanto, pela constituição da primeira fase da cadeia produtiva do ramo da música.

Transformar o que se produz artisticamente em um produto cultural vendável requer a existência de toda uma estrutura espacial. O que leva alguém a estudar música, a querer se profissionalizar nesse campo é a perspectiva de gravar discos e de fazer bons shows. Como isso se concretiza espacialmente é o que se pretende descobrir na referida pesquisa qualitativa. Portanto, os aspectos a serem levantados buscam elucidar algumas questões:

- Onde se formam os músicos do DF?

- Onde e como esses músicos trabalham?

- Que tipo de produto cultural eles estão produzindo?

- Eles estão obtendo sucesso profissional?

- O que falta no DF para que o trabalho deles seja otimizado e projetado nacionalmente?

A partir dos resultados obtidos nessa primeira investigação, será possível detectar os principais elementos que atuam nos sistemas de objetos e de ações do espaço cultural brasiliense, bem como identificar as possíveis hipóteses para os problemas internos e externos ao processo de produção que tornam o mercado cultural da capital brasileira tão incipiente.

Apresentadas as características e investigados os entraves espaciais, serão elaboradas estratégias para melhor explorar o potencial de produção de bens e serviços musicais da capital federal, na expectativa de torná-la um polo de atração para os circuitos regionais do mercado da cultura. 


\subsubsection{Caracterização da área de estudo}

O DF é uma unidade territorial da República Federativa do Brasil criada para abrigar a capital do país e todo o aparato administrativo do governo federal. Sua localização geográfica é entre os paralelos $15^{\circ} 30^{\prime}$ e $16^{\circ} 03^{\prime} \mathrm{S}$ e os meridianos $47^{\circ} 25^{\prime}$ e $48^{\circ} 12^{\prime} \mathrm{W}$, na região Centro-Oeste, ocupando o Centro-Leste do estado de Goiás.

Ele é composto pelo Plano Piloto de Brasília, compreendido pela RA I - onde se localiza a sede administrativa do país - e por outras $27 \mathrm{RAs}^{1}$, que abrigam as chamadas cidades-satélites, distribuídas em uma área de 5.789,16 $\mathrm{km}^{2}$. Duas dessas RAs, Planaltina e Brazlândia, são antigos municípios do estado de Goiás que foram incorporados pela demarcação da nova Unidade da Federação.

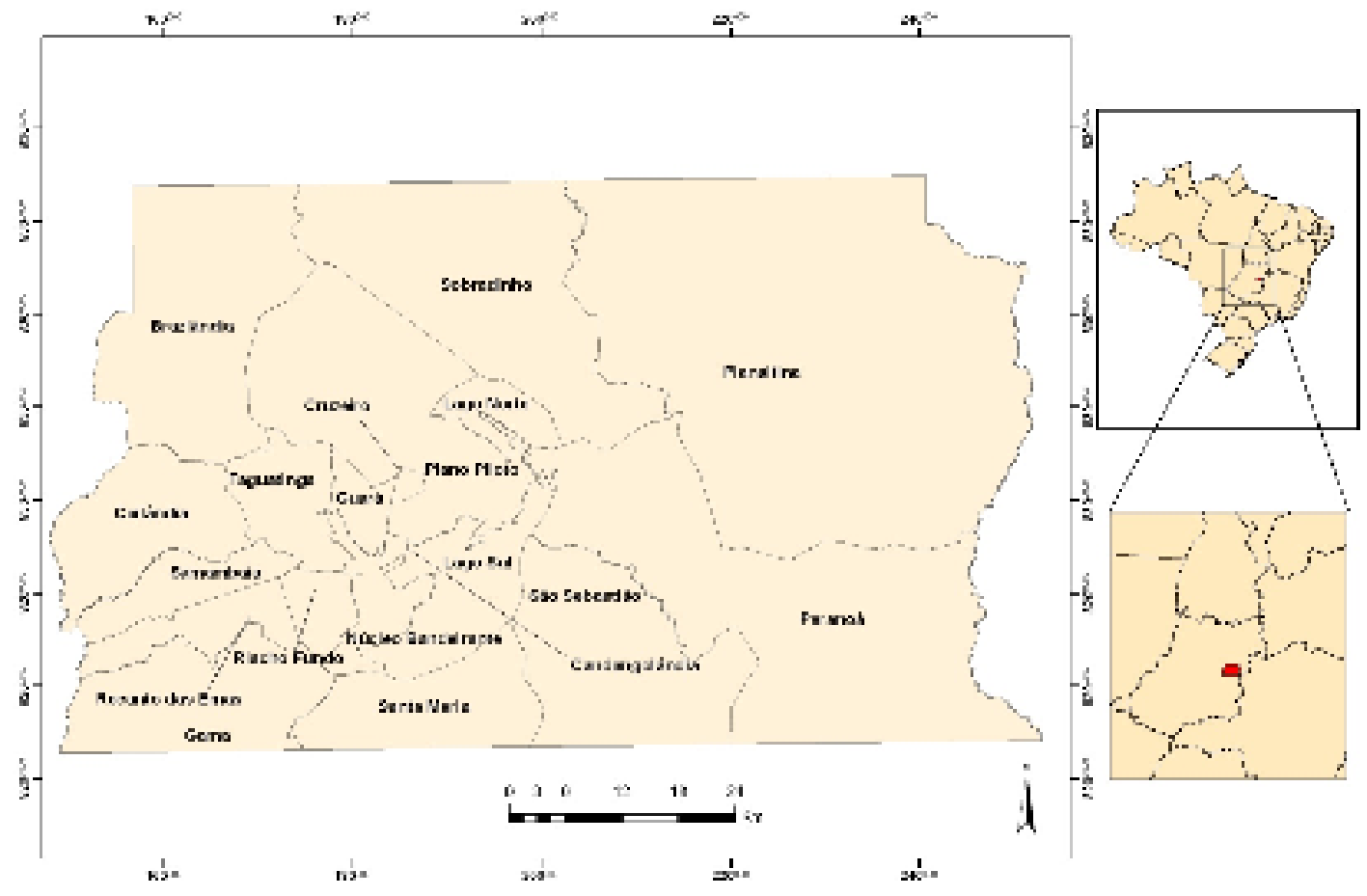

Figura 1 - Mapa das RAs do DF, produzido pelo Laboratório de Sistemas de Informações Espaciais (LSIE) da Universidade de Brasília (UnB).

\footnotetext{
${ }^{1}$ Embora existam 28 RAs, o mapa não contempla todas elas porque ainda não se fez nenhuma atualização oficial dessa informação geográfica.
} 
As cidades-satélites (divididas em RAs) fazem parte do plano urbanístico original do DF, contudo, não possuem o mesmo planejamento urbanístico proposto no Plano Piloto da nova capital. O início de suas edificações contou com a grande população de operários que, ao contrário do que esperavam os idealizadores da capital, não retornaram às suas cidades de origem, o que resultou em um intenso processo de urbanização, na criação de novas cidades - portanto, novas RAs - e no início de um processo de "favelização" de algumas RAs. Como consequência, o espaço urbano brasiliense se tornou altamente segregador, pois os mais pobres foram sendo alocados em áreas cada vez mais distantes do Plano Piloto de Brasília.

A população total do DF está estimada em 2.455.903 habitantes. A taxa de analfabetismo é de 4,35\% e o Índice de Desenvolvimento Humano (IDH) é de 0,844, dois dos melhores indicadores do país ${ }^{2}$.

Embora o Distrito Federal como um todo seja um espaço urbano polinucleado, o recorte espacial desta pesquisa contemplará apenas a RA I - Brasília. Três foram os principais motivos para tal escolha: 1) o fato de que cada cidade que constitui o DF se apresenta como um espaço urbano específico, o que traria muitas dificuldades de análise; 2) é na RA I que se localizam os principais centros de formação de músicos do DF, que são de fundamental importância para que se constitua a primeira fase da cadeia produtiva do ramo musical; 3) a RA I é a que mais polariza e concentra a maior quantidade de fluxos em todo o Distrito Federal.

A RA I do DF ocupa $472,12 \mathrm{~km}^{2}$ de área, sendo $26,31 \mathrm{~km}^{2}$ de área urbana e $445,81 \mathrm{~km}^{2}$ de área rural. Atualmente, ela compreende as Asas Sul e Norte e o Parque Nacional de Brasília. A população total da RA é de 198.422 habitantes, ou seja, 9,6\% de todo o Distrito Federal.

\footnotetext{
${ }^{2}$ Fonte: Instituto Brasileiro de Geografia e Estatística (IBGE). Disponível em: $<$ http://www.gdf.df.gov.br/045/04501022.asp>. Acesso em: 12 maio 2009.
} 


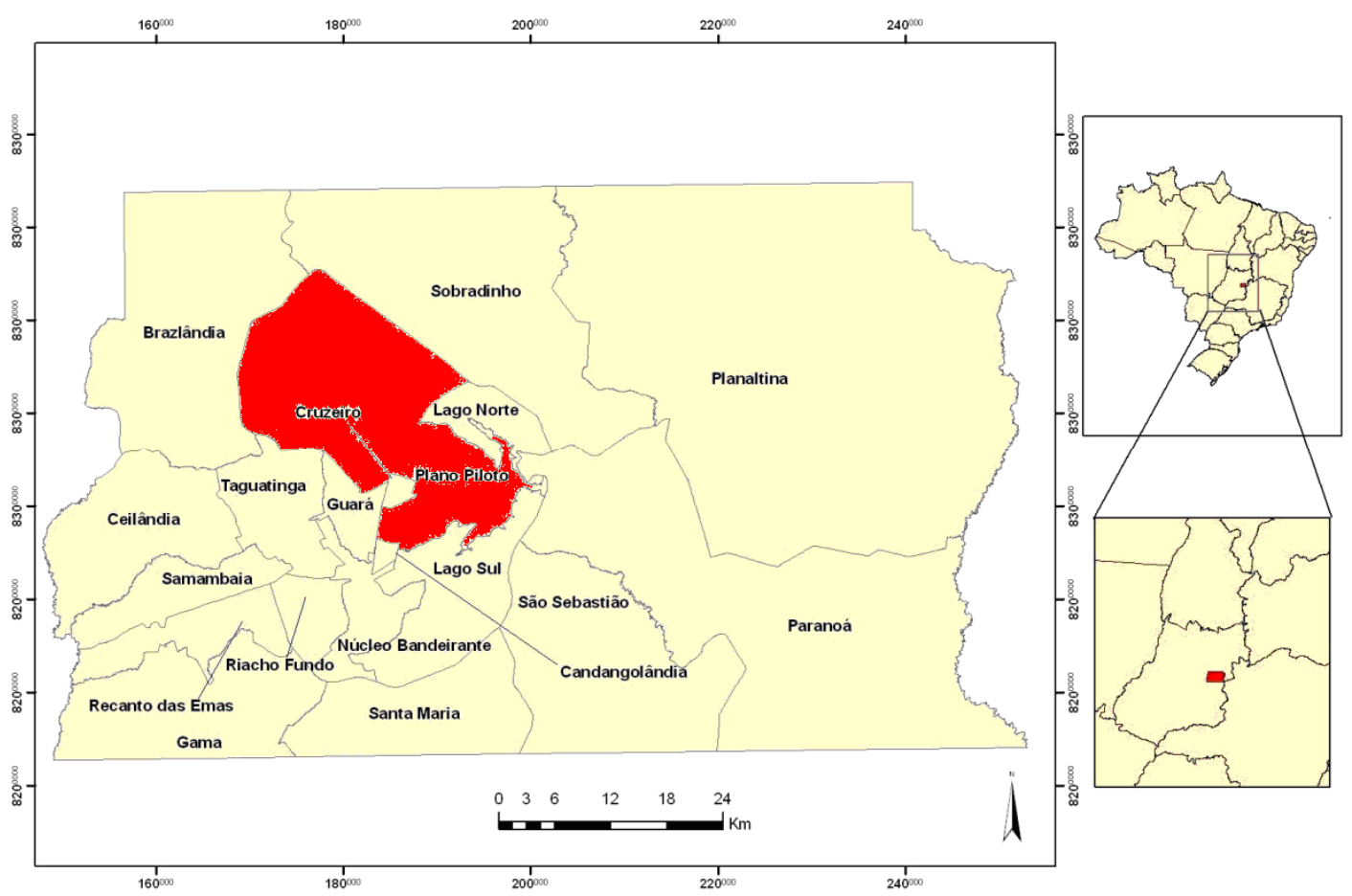

Figura 2 - Mapa da RA I - Brasília, produzido pelo Laboratório de Sistemas de Informações Espaciais (LSIE) da Universidade de Brasília (UnB) (com adaptações).

A RA I é a que apresenta os mais altos indicadores socioeconômicos do DF, com apenas $0,5 \%$ de analfabetos entre a população, quase $25 \%$ com curso superior completo e somente $2,9 \%$ de crianças menores de sete anos fora da escola; $43 \%$ dos domicílios são próprios e quitados e quase $89 \%$ dos habitantes possuem automóvel. Quanto à ocupação principal da população, os números são (ano 2000): 0,17\% na agropecuária, $0,14 \%$ na construção civil, $0,20 \%$ na indústria de transformação, $18,9 \%$ na administração pública, $3,74 \%$ no comércio, $11,14 \%$ no serviço autônomo e 3,46\% no serviço doméstico. A renda per capita, no ano de 2004, era de $\mathrm{R} \$ 1.770,00$, ou 6,08 salários mínimos ${ }^{3}$. Esses dados mostram que o DF representa uma área privilegiada no país.

Centros urbanos cuja população apresenta um alto grau de escolarização e elevado poder aquisitivo tendem a ser espaços onde a produção e o consumo artístico são também elevados, sendo essa, portanto, uma tendência de Brasília.

\footnotetext{
${ }^{3}$ Disponível em: <http://www.gdf.df.gov.br>. Acesso em: 12 maio 2009.
} 


\section{APROXIMANDO MERCADO CULTURAL E ESPAÇO: ASPECTOS TEÓRICOS}

\subsection{A Arte e o Mercado Cultural}

Existem diversas definições para o conceito de cultura. As que dão mais destaque às manifestações artísticas são as formuladas por David Schneider e Clifford Geertz (apud Laraia, 2005): os dois antropólogos consideram que os sistemas simbólicos de cada povo fazem parte de sua cultura. A arte é uma forma de expressão e manifestação espontâneas de elementos simbólicos que contribui profundamente para a formação da identidade de um povo. É, por isso, um patrimônio cultural coletivo e um importante mecanismo de difusão da cultura. Por esse motivo, a produção artística se justifica em si mesma, independentemente de adquirir valor econômico, pois uma obra de arte é única e o seu valor se deve a sua realização simbólica.

Ao longo da história, porém, o acesso à arte foi um privilégio estritamente aristocrático. Os nobres - mecenas - financiavam artistas para produzirem exclusivamente para eles, e as obras eram usadas como instrumentos nas relações de poder. Assim sendo, o mecenato modificou o papel social do artista, pois sua autonomia e sua autossuficiência foram reduzidas na medida em que a produção artística passou a atender aos interesses das elites que a financiavam. A arte adquiriu, então, um caráter utilitário, que, consequentemente, trouxe a possibilidade de ascensão social e econômica aos artistas.

Quando o sistema capitalista se consolida, a relação de mecenato continua existindo, porém, com outra roupagem. A produção artística, por sua vez, passa por mudanças bem mais profundas. De forma alguma isso significa dizer que a cultura foi extinta ou que foi totalmente transformada. O que ocorreu foi uma apropriação e uma adaptação da arte à lógica capitalista.

A mercantilização da arte produziu alterações significativas no processo criativo das obras de arte e na forma como elas passam a ser consumidas. De acordo com Tolila (2007), “é precisamente sob o 'impulso' das evoluções sociológicas que a economia chegou à cultura" (p. 28). Tais "evoluções sociológicas" se situam especialmente no período entre o final do século XIX e o início do século XX, no qual o processo de industrialização foi maciço e gerou profundas modificações espaciais. 
Segundo Bolaño (2000), o desenvolvimento capitalista transformou a produção de arte e a sua forma de financiamento na medida em que criou "condições materiais para a constituição de uma forma capitalista de produção cultural" (p. 103). A mais importante dessas condições foi a reprodutibilidade da obra de arte, que acrescentou um caráter mercantil à produção artística, pois, a partir daí, a obra de arte pôde ser transformada em dinheiro. Isso tornou o trabalho do artista subordinado ao capital (em forma de trabalho produtivo) e às necessidades sociais de consumo. $\mathrm{O}$ resultado do seu trabalho passa a ser um bem de consumo, ou seja, um produto cultural lapidado aos moldes de uma indústria cultural ${ }^{4}$.

Para ser transformada em produto, uma manifestação cultural precisa apresentar algum potencial econômico direto: um livro, um disco, um espetáculo musical ou teatral, entre outros, podem ser considerados produtos culturais desde que atendam a esse pressuposto. No entanto, os bens e serviços ligados à indústria cultural apresentam algumas especificidades fundamentais que os tornam diferentes de todos os outros tipos de mercadoria.

A primeira delas é que a mercadoria cultural tem o seu valor econômico determinado pela conversão do valor simbólico que ela gera (ibid.). Dessa forma, mesmo quando produzidos industrialmente, tais produtos, para os consumidores, possuem o valor de uso de um produto único, ao contrário de qualquer outro bem industrializado.

Em segundo lugar, diferentemente do que ocorre em outros setores, os bens e serviços culturais são classificados como não rivais e não exclusivos, o que significa que são bens de consumo coletivo e que o ato de consumi-los não impede que outros indivíduos o façam simultaneamente e de forma plena (Tolila, 2007).

A última - mas não menos importante - especificidade do setor cultural é que a definição do critério de qualidade dessa categoria de produto não pode ser baseada em uma medida universal e consensual, mas, sim, a partir de critérios subjetivos. Para Bolaño (2000), a resposta para diminuir o alto grau de aleatoriedade na definição da qualidade é dada quando a indústria "mantém a ilusão de unicidade" do produto cultural (ideia esta que é análoga à da "convenção de "originalidade"” apresentada por Tolila,

\footnotetext{
${ }^{4}$ Vale ressaltar, no entanto, dois pontos importantes a respeito da arte como setor da economia: 1) a arte como bem de consumo é um tipo específico que se diferencia da arte "pura". A arte pela arte, embora não tenha sido extinta e não tenha perdido o seu lugar de fala na sociedade, não interessa ao mercado. Portanto, não há, necessariamente, uma ligação direta entre o crescimento do consumo de bens culturais e a redução da qualidade do que é produzido artisticamente; 2) o setor cultural possui características específicas que tornam a análise econômica da cultura diferente de todos os demais setores.
} 
2007). Em outras palavras, é uma busca voluntária pela manutenção da "singularidade" dos produtos, que se concretiza por meio de algumas estratégias ${ }^{5}$ desenvolvidas pelo mercado cultural com o intuito de minimizar tanto o grau de incerteza na produção e consumo, quanto para criar alguns "padrões" de qualidade para o que é produzido.

Outro aspecto que merece ser mencionado é o fato de que, no caso das artes, o conceito de produtividade é de difícil introdução, pois, para o artista, o trabalho é um fim em si mesmo, não apenas um fator de produção ${ }^{6}$.

Todos esses fatores tornam muito incertas as condições de valorização do produto cultural. Por esse motivo, "uma das características do setor cultural é o papel, muito mais importante do que em vários outros setores, das considerações especulativas e, portanto, do valor da informação, a capacidade de interpretá-lo, o controle de seus circuitos" (ibid., p. 33). Assim, na economia do setor cultural, também em contraposição aos outros setores, é a lógica da oferta que predomina, não a da demanda.

Nenhuma dessas características, entretanto, impediu que o mercado cultural se constituísse como um setor da economia. Segundo Brant,

Para estimular o desenvolvimento da cultura nacional é preciso compreendê-la [a arte] como um processo complexo, que conjuga uma vasta cadeia produtiva, com efeito em uma outra gama de agentes sociais e econômicos. O conceito de 'Espiral Cultural' foi gerado justamente para demonstrar o poder sinérgico entre a dinâmica do processo de desenvolvimento da cultura em interação com estes agentes (2004, p. 52).

De acordo com Tolila (2007), um ramo de produção "pode ser representado como uma seqüência de operações que se sucedem desde o tratamento das matériasprimas até a elaboração do produto final”' (p. 38). No caso da cultura, esses ramos são a música, o cinema e a literatura. Ainda segundo o autor, no setor cultural, cada ramo de produção é dividido em cinco fases distintas, nas quais diversos agentes participam (Tabela 1):

1) Fase de criação, na qual o artista concebe a sua obra. É a idéia inicial do que se tornará uma obra de arte;

\footnotetext{
5 A estandardização, a serialização, a renovação, a criação de catálogos e a presença constante de propaganda são algumas dessas estratégias.

${ }^{6}$ Segundo Celso Furtado (apud Álvarez, 2003).
} 
2) Fase de edição e produção: é o momento no qual o protótipo criado pelo artista se transforma em bem cultural, ou seja, ele é moldado de acordo com as exigências do mercado. Esta é considerada uma fase-chave da indústria cultural, pois é a "ponte" entre a etapa inicial e todas as posteriores; é a fase que exige os mais pesados investimentos e na qual o risco é máximo; é também a mais sujeita à incorporação de novas tecnologias;

3) Fase de fabricação, que é o momento em que o trabalho artístico se materializa: a prensagem e o acondicionamento de CDs e DVDs, a impressão de um livro e o trabalho técnico feito nos filmes;

4) Fase de distribuição, na qual o(s) produto(s) é(são) colocado(s) à disposição para venda;

5) Fase da comercialização pública: o consumidor tem acesso ao(s) produto(s).

TABELA 1 - RECAPITULAÇÃO DOS AGENTES DE CADA RAMO

\begin{tabular}{|c|c|c|c|}
\hline & Cinema & Música & Literatura \\
\hline Fase 1: Criação & $\begin{array}{l}\text { Roteiristas, diretores, } \\
\text { intérpretes }\end{array}$ & $\begin{array}{l}\text { Compositores (letra e/ou } \\
\text { música) }\end{array}$ & Autor de manuscrito \\
\hline $\begin{array}{l}\text { Fase 2: Edição / } \\
\text { Produção }\end{array}$ & Produtor & Editor, produtor & Editor \\
\hline Fase 3: Fabricação & $\begin{array}{l}\text { Indústrias técnicas, } \\
\text { fabricação de filmes } \\
\text { virgens }\end{array}$ & $\begin{array}{l}\text { Prensagem e } \\
\text { acondicionamento de CDs }\end{array}$ & Impressor \\
\hline $\begin{array}{l}\text { Fase 4: } \\
\text { Distribuição }\end{array}$ & Distribuidor & $\begin{array}{l}\text { Logística, promoção e } \\
\text { gestão de catálogos }\end{array}$ & $\begin{array}{l}\text { Difusor (promoção dos } \\
\text { catálogos nos pontos de } \\
\text { venda) } \\
\text { Distribuidor (logística de } \\
\text { entrega e de gestão física e } \\
\text { financeira das obras) }\end{array}$ \\
\hline $\begin{array}{l}\text { Fase 5: } \\
\text { Comercialização }\end{array}$ & Exibidores & $\begin{array}{l}\text { Lojas de discos, megalojas } \\
\text { especializadas, } \\
\text { hipermercados }\end{array}$ & $\begin{array}{l}\text { Livrarias, megalojas } \\
\text { especializadas, hipermercados }\end{array}$ \\
\hline
\end{tabular}

Fonte: Tolila, 2007, p. 41 (com adaptações).

Todas essas fases e seus respectivos agentes estão embutidos no conceito de “espiral cultural” apresentado por Brant (2004), que ressalta, ainda, que outros agentes não necessariamente ligados à produção também interferem no processo de produção 
cultural, tais como: organizações culturais (públicas, privadas ou do terceiro setor), empresas ou empresários dispostos a investir no financiamento e na difusão da cultura; o poder público, que é responsável pela formulação, gestão e aplicação de leis de incentivo e difusão da cultura; o meio acadêmico, que forma estudiosos e teóricos do tema, além, é claro, do próprio público consumidor de cultura.

Segundo o mesmo autor, a dinâmica da espiral funciona de forma cíclica e em progressão geométrica. Para que isso ocorra de forma eficaz, é preciso haver uma base estrutural e uma rede de relações econômicas e sociais que permitam a formação dos anéis que compõem a base da espiral. Cada ciclo é constituído de um processo cultural que, quando completado, possibilita a ampliação da base. $\mathrm{O}$ aumento da base permite que novos agentes trabalhem na modelagem de um novo anel, iniciando-se um novo ciclo.

Para estimular o desenvolvimento do setor, no entanto, é de suma importância que haja uma interação e uma cooperação muito fortes entre os diversos agentes que operam a produção. Tanto Brant (2004) quanto Tolila (2007) apontam que a dinâmica do mercado é bastante alterada quando ocorre algum desequilíbrio entre eles ou entre as fases de produção. Em um setor em que o grau de incerteza é alto, há uma necessidade latente de se recuperar o valor agregado. Consequentemente, também se torna alto o nível de competitividade entre os agentes produtores.

Tolila (2007) faz outra observação importante no que diz respeito à indústria cultural: o modelo de organização das empresas que atuam no ramo. Em sua opinião, o modelo que predomina é o chamado oligopólio de franja (denominação dada por Georges Stigler), que apresenta um "centro oligopolístico" que "coexiste com uma franja concorrencial que age em 'nichos' de mercado e é capaz de responder às demandas específicas dos consumidores" (p. 44). E acrescenta: "O oligopólio de franja é a estrutura dominante nas indústrias culturais em que a estrutura oligopolística é acompanhada por uma multidão de empresas independentes". As chamadas "empresasfranja", devido à sua vulnerabilidade diante das gigantes que compõem o centro, denominadas majors, só se estabelecem no mercado nas fases em que estas não se desenvolvem de maneira absoluta.

As empresas-franja que entram no ramo e conseguem sobreviver são, geralmente, as que trabalham com edição e produção, funções que se submetem menos às homogeneizações do mercado e, por isso, são menos exercidas pelas majors. Estas controlam, isso sim, as etapas de difusão e reprodução industrial. Pode-se pensar, então, 
que é uma grande vantagem para uma empresa menor estar inserida no circuito de produção controlado por uma major. No entanto, na prática, essa não é uma constatação tão óbvia. Tolila (2007) explica que,

Nos mercados culturais, e isso se torna mais verdadeiro com as possibilidades de difusão oferecidas pela tecnologia digital e a Internet em especial, é evidente que quem detém um forte poder de distribuição poderá não só vender melhor seus próprios produtos, como também "sujeitar" melhor seus competidores e analisar melhor e mais rápido as evoluções do mercado. Posição de força e antecipação se aliam para dar às empresas em causa uma verdadeira vantagem competitiva (p. 44-45).

Isso significa que, mesmo fazendo parte da estrutura produtiva, uma empresafranja dificilmente consegue competir em pé de igualdade com uma major porque quem tem o poder sobre as etapas de difusão e distribuição é quem domina o mercado. Um fator determinante na sobrevivência das empresas menores é que estas, muitas vezes, atendem a demandas específicas, que formam nichos de mercado que não interessam às majors devido aos custos de produção.

Pela diferenciação característica dos produtos culturais, a pequena empresa encontra uma vantagem concorrencial que não teria numa lógica econômica dominada pelos custos. Essa estratégia só pode ser eficaz no início da cadeia de produção do ramo (fase 2 , edição e produção) porque as independentes têm muita dificuldade de enfrentar as "majors" na distribuição, em que os problemas de custos são determinantes (ibid., p. 45).

Mais do que uma simples relação de coexistência, o que ocorre entre as empresas é uma espécie de cooperação mútua - porém, sempre com maior vantagem paras as majors. É interessante para estas que as pequenas empresas e/ou as empresas independentes existam, pois são elas que investem na "renovação da criatividade artística", são elas que investem "em setores em que a rentabilidade não é garantida e assumindo os riscos que as grandes empresas se recusam a assumir [...]" (ibid., p. 46). As grandes empresas, além de não terem de se preocupar com as arriscadas primeiras pesquisas de novos produtos, detêm os mecanismos de difusão de distribuição porque têm muito mais capital. Em outras palavras, já recebem um produto garantidamente rentável para aplicar seus planos comerciais e, por outro lado, "são as primeiras a se 
inteirar das evoluções das modas e dos gostos" (ibid.), o que influencia na descoberta de novos produtos.

Diante desse panorama, fica evidente que dinamizar o setor cultural não é uma tarefa de fácil execução. A simples existência de artistas (oferta) e de pessoas que consumam suas obras (demanda) é fundamental, mas não suficiente para que se chegue a um desenvolvimento econômico, social e (menos ainda) regional por meio da arte em um contexto de mercado, assim como propõe Brant.

\subsection{Mercado Cultural e Espaço}

O espaço geográfico é formado por elementos fundamentais que não só contribuem para a sua definição como também atuam no seu desenvolvimento e na sua evolução. De acordo com Santos (1985, p. 6), “os elementos do espaço seriam os seguintes: os homens, as firmas, as instituições, o chamado meio ecológico e as infraestruturas". Esses elementos não existem nem atuam isoladamente: há relações tanto de um elemento com os outros como com o lugar no qual está inserido. Tal dinâmica entre os elementos espaciais se constitui em estruturas que formam sistemas em que o comando é dado "pelo modo de produção dominante nas suas manifestações à escala do espaço em questão" (ibid., p. 14) e que se adaptam ao meio local. Dessa forma, a transformação desses sistemas - que leva às transformações espaciais - depende tanto de fatores externos a eles como também de modificações do valor e do significado que os elementos que os constituem assumem no decorrer dos momentos históricos que os engendram. Ou seja, o espaço está constantemente sendo produzido e modificado em um movimento dialético, e o que determina e condiciona esse movimento são a estrutura e os sistemas que o compõem.

No entanto, não é possível chegar a uma apreensão empírica do espaço total. Em termos práticos, ele se apresenta apenas em nível conceitual. Para fazer uma análise do espaço total, é necessário utilizar um recorte espacial, uma fração representativa dessa totalidade, que seja constituída por elementos espaciais organizados em uma estrutura espacial. Assim sendo, uma análise que apresenta apenas uma descrição ou classificação dos elementos de determinado espaço não passa de mera visão superficial e incompleta da realidade, pois "é somente a relação que existe entre as coisas que nos permite realmente conhecê-las e defini-las" (ibid., p. 14). Além disso, “a totalidade social é 
formada da união desses dados contraditórios, da mesma maneira que o espaço total" (p. 17).

Ainda de acordo com o autor (ibid., p. 16), uma estrutura espacial é formada por elementos homólogos (elementos de uma mesma classe) e não homólogos (elementos pertencentes a classes diferentes). Assim sendo, pode-se dizer que

A estrutura espacial é algo assim: uma combinação localizada de uma estrutura demográfica específica, de uma estrutura de produção específica, de uma estrutura de renda específica, de uma estrutura de consumo específica, de uma estrutura de classes específica e de um arranjo específico de técnicas produtivas e organizativas utilizadas por aquelas estruturas e que definem as relações entre os processos presentes (p. 17).

Com base nisso, pode-se dizer que o funcionamento sistêmico do mercado cultural apresentado por Brant e Tolila dialoga diretamente com a dialética do espaço, pois os autores deixam claro que o encadeamento das atividades que garantem a constituição do respectivo processo produtivo depende da existência de relações espaciais entre seus agentes. Em virtude disso, ao considerar a definição de espaço geográfico dada por Santos em A natureza do espaço (2008), pode-se propor uma análise espacial do mercado cultural.

Se “o espaço é formado por um conjunto indissociável, solidário e também contraditório de sistemas de objetos e sistemas de ações, não considerado isoladamente, mas como o quadro único no qual a história se dá” (ibid., p. 63), a arte, como importante parte integrante da cultura, é uma categoria de objetos que formam o espaço, e a dinâmica de produção e de consumo da arte constitui um sistema de objetos próprio, objetos estes que possuem uma funcionalidade para além do valor simbólico ${ }^{7}$. Dessa forma, estudar os fenômenos espaciais ligados à economia de bens e serviços culturais é

reconhecer o valor social dos objetos [produtos culturais], mediante um enfoque geográfico. A significação geográfica e o valor geográfico dos objetos vêm do papel que, pelo fato de estarem em contigüidade,

\footnotetext{
${ }^{7}$ Santos, citando a classificação de objetos proposta por Bense, afirma: “Os objetos de arte são 'os menos determinados funcionalmente', já que sua apreciação reside em fatores externos aos mesmos, localizados no observador, isto é, no sujeito" (2008, p. 70). Ele cita ainda a idéia de "sistema da moda", de Barthes, pois "a moda é também um processo no qual os objetos já nascem com data certa de morrer [quanto a sua apreciação de valor]" (ibid., p. 71). Santos acrescenta que esse é um "aspecto dos objetos técnicos atuais, isto é, a rapidez com que são substituídos e perdem valor" (ibid.). O mercado cultural talvez seja o melhor exemplo dessa efemeridade.
} 
formando uma extensão contínua, e sistematicamente interligados, eles desempenham no processo social (ibid., p. 77).

Além disso, os sistemas de objetos estão ligados diretamente à paisagem. Segundo Santos,

A partir do reconhecimento dos objetos na paisagem e no espaço, somos alertados para as relações que existem entre os lugares. Essas relações são respostas ao processo produtivo no sentido largo, incluindo desde a produção de mercadorias à produção simbólica (ibid., p. 72).

Um sistema de objetos também permite que se configure um sistema de ações. Este, por sua vez, recria e/ou cria novos objetos. O autor ainda compara essa dinâmica com os escritos de Marx, ao sugerir o sistema de objetos como "um conjunto de forças produtivas" e como o sistema de ações "nos daria um conjunto de relações sociais de produção" (ibid., p. 63) .

Para falar sobre o que é "ação", o mesmo autor (2008) apresenta definições de diversos autores. Os pontos comuns entre todos eles é que: uma ação pressupõe uma intencionalidade, modifica a realidade na qual ela acontece e pode ocorrer concomitantemente com outras ações. Porém, "a ação humana é subordinada a normas, escritas ou não, formais ou informais, e a realização do propósito reclama sempre um gasto de energia" (ibid., p. 78).

Além disso, ao citar Anthony Giddens, Santos ressalta que é importante diferenciar "intenção" de "propósito", pois "a intenção é central na prática diária, enquanto o propósito supõe ambições ou projetos a longo prazo" (ibid., p. 79). No entanto, Giddens ressalta que o ser humano, na maioria das vezes, age antes de ter uma finalidade clara em mente, e que isso se aplica claramente nos dias de hoje, pois a realidade do consumo acaba por reforçar deliberadamente essa impulsividade. Por conta disso, as ações se tornam “cada vez mais distantes dos fins próprios do ser humano e do lugar” porque, no momento atual, fortemente marcado pelo processo de globalização, “ações que se exercem num lugar são produto de necessidades alheias, de funções cuja geração é distante e das quais apenas a resposta é localizada naquele ponto preciso da superfície da Terra" (ibid., p. 80).

\footnotetext{
${ }^{8}$ Tal visão marxista é exatamente a utilizada por Bolaño para analisar a relação entre o trabalho do artista e o da indústria na produção de bens culturais na atualidade.
} 
Portanto, os agentes que decidem pelas ações de todos não são os próprios indivíduos, mas

os governos, as empresas multinacionais, as organizações internacionais, as grandes agências de notícias, os chefes religiosos [...]. A escolha do homem comum, em muitas das ações que empreende, é limitada. Frequentemente, o ator é apenas o veículo da ação, e não seu verdadeiro motor. Mas é sempre por sua corporeidade que o homem participa do processo de ação (Masini apud Santos, 2008, p. 80).

Hoje, as ações consideradas racionais o são porque nelas atua uma racionalidade totalmente alheia que é fruto do meio técnico atual, caracterizado por uma precisão nunca antes vista. Ou seja, é uma racionalidade cada vez mais técnica e menos humana; "a racionalidade do que é fim para outrem acaba sendo a racionalidade do meio e não a do sujeito" (Santos, 2008, p. 81).

Continuando a seguir o raciocínio de Santos (ibid., p. 82-83), ação é algo exclusivo do ser humano. No meio natural, não existe ação, porque seus indivíduos não são dotados de objetivos, finalidades. As ações resultam de necessidades humanas reais ou criadas e são essas necessidades que produzem as funções. Tais funções, naturalmente, chegam até os objetos, pois são elas que conduzem à criação e ao uso de objetos, ou seja, formas geográficas.

É preciso ressaltar que uma ação, qualquer que seja, é sempre dotada de intencionalidade. Retomando o conceito de espaço apresentado anteriormente, observase que objetos e ações são inseparáveis e, segundo Heidegger, também condicionados à paisagem, pois “o 'onde' determina o 'como' do Ser, porque Ser significa presença” e porque "a ação é ação em uma paisagem e é a paisagem que dá forma à ação" (apud Santos, 2008, p. 93). Todavia, a ação humana não produz resultados apenas por conta da racionalidade que gera a intenção. Há também um fator de imponderabilidade, advindo tanto do caráter humano do meio quanto da própria natureza humana e atuando nos resultados das ações. Por conta disso, os atores podem se deparar com "ações que não são consequência de decisões" e de "ações intencionadas (que) podem conduzir a resultados não-intencionados (sic)" (ibid., p. 94) 9

\footnotetext{
${ }^{9}$ Essa imprevisibilidade dos resultados é apresentada por Ricoeur e Moles (apud Santos, 2008, p. 95) com a denominação de "autonomia da ação" e de "evento", respectivamente.
} 
Quando as ações permitem que vários objetos se organizem a fim de se interrelacionar - tendo ou não uma estrutura de comunicação entre eles -, há indícios de que esses objetos podem estar constituindo uma rede.

Ainda de acordo com Santos (2008), para a ciência geográfica, as redes são definidas como um conjunto de relações entre agentes espaciais que pode ou não ter uma infraestrutura territorial para a interligação de pontos. Estes podem ser quaisquer dos elementos do espaço.

Para se identificar uma rede em um momento atual, é necessário

um estudo estatístico das quantidades e das qualidades técnicas, mas, também, a avaliação das relações que os elementos da rede mantêm com a presente vida social, em todos os seus aspectos, isto é, essa qualidade de servir como suporte corpóreo do cotidiano (p. 263).

Ademais, é igualmente imprescindível uma observação da

idade dos objetos [...] e, também, da quantidade e da distribuição destes objetos, do uso que lhes é dado, das relações que tais objetos mantêm com outros fora da área considerada, das modalidades de controle e regulação de seu funcionamento (ibid.).

Embora, no passado, as redes fossem configuradas de uma forma mais espontânea, nos dias de hoje, com os avanços tecnológicos do meio técnico-científicoinformacional, há como interferir na montagem de uma rede, pois há como antever as funções que ela irá exercer no espaço e, com isso, atuar na forma como ela irá se constituir, na sua estrutura material e na forma de geri-la ${ }^{10}$.

Como, atualmente, o processo produtivo mundial é marcado pela prevalência da circulação sobre a produção, são os fluxos que acabaram se tornando o principal parâmetro para explicar uma situação. O lugar também assume um papel central, pois, com as constantes mudanças nas virtualidades de cada localização, eles têm de estar constantemente aprimorando suas vantagens comparativas e desenvolvendo novas potencialidades a fim de atrair os principais fluxos que compões as redes.

Ao falar em "espiral cultural”, Brant (2004) apresenta uma forma de organização do mercado cultural que é espacializada e pressupõe uma rede de relações entre os

\footnotetext{
${ }^{10}$ As redes, inclusive, tiveram e ainda têm um papel determinante no processo de globalização.
} 
agentes da espiral; a cadeia produtiva dos bens culturais apresentada por Tolila (2007) também é caracterizada por um funcionamento em rede. 


\section{PRIMEIRA FASE DA CADEIA PRODUTIVA DA MÚSICA NA RA I - BRASÍLIA}

A primeira fase de qualquer cadeia produtiva no ramo musical é a da composição. É na RA I que se encontram os principais centros de formação de músicos: o Centro de Educação Profissional - Escola de Música de Brasília (CEP-EMB), a Escola de Choro Raphael Rabello e o Departamento de Música da Universidade de Brasília (UnB). As três escolas são consideradas centros de excelência no ensino de música no Brasil.

\subsection{Centro de Educação Profissional - Escola de Música de Brasília (CEP-EMB)}

A Escola de Música de Brasília (EMB) foi fundada em 1974 por iniciativa do maestro Levino de Alcântara, com o intuito de nuclear o ensino de música no DF que, até então, era dividido entre o Centro de Ensino Médio Elefante Branco, na Asa Sul, e o Centro de Ensino Médio Asa Branca, localizado em Taguatinga. O maestro Levino de Alcântara foi, também, o primeiro a reger o Madrigal de Brasília, um coro de cantores profissionais vinculado à Escola de Música e que continua existindo nos dias de hoje.

Os primeiros cursos da EMB foram: violino, viola, violoncelo, contrabaixo, flauta transversal, flauta doce, oboé, clarineta, trompa, fagote, trompete, trombone e tuba. A EMB também mantinha uma orquestra sinfônica composta por professores e alunos. Portanto, o enfoque era, fundamentalmente, na música erudita.

Em 1985, o então diretor Carlos Galvão implantou um núcleo de música popular, visando a aumentar o leque de estilos musicais oferecidos nos cursos. Galvão também foi o responsável pela introdução de vários outros núcleos, tais como o de regência, o de música de câmara, o de informática aplicada e o de música contemporânea, além da estruturação da musicalização infantil. Mais um ponto interessante e diferencial da EMB é o ensino de musicografia em Braille, com o intuito de incluir alunos com deficiência visual.

Outra administração marcante foi a do professor Luiz Alberto Tibana (1996-97), que implantou o núcleo de música antiga e formulou projetos de extensão comunitária do trabalho realizado pela escola. 
Em 1998, o maestro Carlos Galvão reassumiu a direção da escola e implantou o núcleo de tecnologia em música, para que os alunos aprendessem a utilizar software de edição de partituras e técnicas de gravação e sonorização de espetáculos. Foi também sob a direção de Galvão que se realizou um convênio de investimentos com o Programa de Expansão da Educação Profissional (Proep) do Ministério da Educação, que transformou a EMB no primeiro Centro de Educação Profissional (CEP) voltado para a formação de músicos em nível técnico do país.

Atualmente, o CEP-EMB é uma escola mantida pela Secretaria de Estado de Educação do governo do Distrito Federal e suas parceiras e continua sendo dirigida por Carlos Galvão. Oferece 36 cursos técnicos e 58 cursos básicos de formação profissional em todas as modalidades instrumentais e vocais. Localiza-se na $602 \mathrm{Sul}$ e atende alunos de todas as cidades do DF. A estrutura física conta com 71 laboratórios de ensino, nove salas para as funções administrativas, biblioteca, instrumentoteca (sala com diversos instrumentos musicais oferecidos para empréstimo aos alunos), musicoteca (sala com grande acervo de partituras para consulta), sala de multimeios e dois auditórios com diferentes capacidades e características ${ }^{11}$.

Apesar de todas as dificuldades que uma escola pública enfrenta no Brasil, o CEP-EMB consegue manter a qualidade na formação de seus alunos. Uma das principais formas de captação de recursos é a Associação de Pais, Alunos e Mestres (Apam), que recolhe uma contribuição mensal dos pais de alunos, destes mesmos e de quem mais queira doar alguma quantia à escola. Com o dinheiro arrecadado, realizamse reformas e compram-se materiais e instrumentos, entre outras coisas.

Ponto marcante do CEP-EMB, também, é o Curso Internacional de Verão, que acontece uma vez por ano, sempre em janeiro. O curso é reconhecido pelo alto nível das aulas e do desempenho dos alunos e professores convidados, que vêm de diversos estados e países. Esse é, de fato, um dos mais importantes eventos musicais do Brasil.

\footnotetext{
${ }^{11}$ Disponível em: <http://www.emb.com.br>. Acesso em: 15 maio 2009.
} 


\subsection{Escola de Choro Raphael Rabello}

A Escola de Choro Raphael Rabello foi fundada em 29 de abril de 1998 e é a única escola do Brasil - e do mundo - voltada para o ensino desse gênero musical. O fundador da escola é o jornalista Henrique Filho, conhecido como "Reco do Bandolim", que é, desde então, o presidente do Clube do Choro.

A intenção era montar uma escola nos moldes dos grandes institutos de jazz norte-americanos, mas que valorizasse, preservasse e difundisse a cultura brasileira. " $\mathrm{O}$ choro é considerado o jazz brasileiro, não só pela riqueza harmônica, mas também pelas possibilidades de improvisação que abre para o músico", diz Reco.

A proposta, elaborada com a colaboração dos também jornalistas Carlos Henrique Santos e Ruy Fabiano e com a concepção pedagógica de Maurício Carrilho, foi encaminhada para a diretoria do Clube do Choro de Brasília, que, após analisar o projeto, o aprovou. A sugestão de nomear a escola fazendo uma homenagem ao grande violonista Raphael Rabello foi aprovada unanimemente.

Inicialmente, a escola oferecia os cursos de bandolim, violão de seis e de sete cordas, saxofone, pandeiro e cavaquinho. Posteriormente, foram acrescentados os cursos de flauta transversal e clarineta. Os alunos também contam com a realização de oficinas de músicos renomados do gênero, visando não só ao contato com grandes nomes do choro, mas, principalmente, ao aprimoramento na formação musical.

Atualmente, a escola funciona no Clube do Choro de Brasília, localizado no Setor de Divulgação Cultural, no Eixo Monumental, e aguarda a construção da sede definitiva, cujo projeto é assinado pelo grande arquiteto Oscar Niemeyer e que depende de licitação e dos recursos do governo do Distrito Federal ${ }^{12}$.

Tanto na Escola de Choro como na EMB, a demanda por vagas é maior do que a capacidade estrutural das instituições. Consequentemente, as duas escolas, com o intuito de tornar o acesso o mais democrático e idôneo possível, desenvolveram dois mecanismos para o preenchimento de novas vagas: 1) sorteio de vagas para alunos iniciantes; e 2) testes de aptidão para alunos com alguma experiência musical. Igualmente marcante e comum às duas escolas é a disponibilização de instrumentos para empréstimo a alunos que não têm instrumento próprio. Assim como a EMB, a Escola de Choro de Brasília atende a alunos de todas as cidades do Distrito Federal.

\footnotetext{
${ }^{12}$ Disponível em: $<$ http:// www.clubedochoro.com.br >. Acesso em: 15 maio 2009.
} 


\subsection{Departamento de Música da Universidade de Brasília (MUS/UnB)}

O Departamento de Música da Universidade de Brasília (MUS/UnB) é um dos departamentos que compõem o Instituto de Artes (IdA). A maioria dos cursos do bacharelado em Música foi reconhecida em 1969. O aluno pode escolher graduação nos seguintes cursos: canto, clarineta, composição, contrabaixo, fagote, flauta, oboé, piano, regência, saxofone, trombone, trompa, trompete, viola, violão, violino e violoncelo. Há também a opção de habilitação em Licenciatura, bem como a dupla habilitação.

O candidato a uma vaga no curso de Música, além de ter de ser aprovado no exame vestibular aplicado a todos os interessados em ingressar na UnB, também é avaliado em uma Prova de Habilidades Específicas. Essa prova tem o objetivo de averiguar se o candidato possui alguns conhecimentos básicos e aptidão necessários para seguir a carreira de músico.

O tempo mínimo para colar grau é quatro anos e o enfoque do curso é a música erudita. Não há um curso ou matérias específicas que contemplem a música popular ${ }^{13}$.

\footnotetext{
${ }^{13}$ Disponível em: < http://www.unb.br>. Acesso em: 15 maio 2009.
} 


\section{RESULTADOS DA PESQUISA QUALITATIVA}

O questionário de pesquisa foi respondido por dez pessoas, entre os dias $1^{\circ}$ e 17 de junho de 2009. As entrevistas foram feitas tanto presencialmente quanto pela Internet, por meio de uma versão eletrônica do questionário, disponibilizada no sítio www.encuestafacil.com.

Para preencher o questionário, selecionaram-se músicos que moram em diversas cidades do DF, mas que trabalham em uma das três principais instituições de ensino de Música do $\mathrm{DF}^{14}$ e/ou tiveram a sua formação profissional ligada a alguma delas.

Ao analisar as respostas dadas pelos músicos e professores entrevistados, observa-se, de imediato, que todos eles, mesmo que hoje trabalhem em outras escolas, afirmaram ter a sua formação total ou parcial em uma das três principais escolas de Música do Distrito Federal. Mesmo o entrevistado que veio de fora do Brasil teve a sua vinda vinculada à vontade de estudar na Escola de Música de Brasília. Outro entrevistado, que nasceu em São Paulo e se licenciou em Música pela Universidade Federal do Ceará, veio para a capital federal porque passou no concurso do CEP-EMB para professor.

Isso mostra que, de fato, essas três instituições - CEP-EMB, Escola de Choro Raphael Rabello e MUS/UnB - têm importância espacial não apenas em Brasília, mas também atraem professores de Música, instrumentistas, cantores e aspirantes a músico do Brasil inteiro.

Um aspecto digno de nota é que todos os entrevistados apontaram a música como a sua principal fonte de renda. Vale frisar, porém, que essa renda advém, predominantemente, do ensino de Música, não da realização de shows e/ou da venda de discos. Tal fato evidencia que, em Brasília, é possível viver exclusivamente de música e a razão para isso pode ser a hipótese de que existe uma demanda por aulas de Música e por produtos culturais. Essa hipótese se reforça nas respostas obtidas dos entrevistados quanto às maiores dificuldades encontradas na realização de seu trabalho. Uma das alternativas era a falta de público ou de alunos, a qual não foi assinalada por nenhum dos professores. Os itens mais marcados para essa pergunta foram: falta de produtores (tanto de shows como de artistas) e de estrutura para a realização de shows.

\footnotetext{
${ }^{14}$ Com base em algumas das informações obtidas na pesquisa, elaborou-se um mapa em que estão localizadas as escolas de Música onde os entrevistados trabalham e os lugares onde se apresentam com mais frequência.
} 
Com relação à gravação de $\mathrm{CDs}$, alguns pontos importantes merecem ser mencionados:

$>$ A maioria dos entrevistados já gravou pelo menos um disco e essa(s) gravação(ões) foi(foram) feita(s) no próprio Distrito Federal;

$>$ No que respeita à etapa de prensagem do $\mathrm{CD}$, apenas um entrevistado afirmou ter sido feita no DF - porque as cópias foram confeccionadas em uma escala não industrial (cópias caseiras e no próprio estúdio de gravação). Esse dado indica que é relativamente fácil gravar um disco no $\mathrm{DF}$, até mesmo devido à abundância de estúdios de ensaio e gravação espalhados não somente no Plano Piloto, como também nas cidades-satélites;

$>$ Quanto à venda dos discos, existe certa precariedade, pois todos os entrevistados disseram que eles mesmos ou os músicos que os contrataram como free-lancers vendem seus próprios discos.

A respeito do último ponto mencionado, cabe ressaltar que, segundo Santos (1985), “a capacidade maior ou menor de fazer circular rapidamente o produto é condição, para cada firma, de sua capacidade maior ou menor de realização, ou, em outras palavras, do seu poder de mercado [...]" (p. 62). Ainda de acordo com Santos, “não basta produzir muito. [...] É indispensável transformar as massas produzidas em fluxos, para reaver o dinheiro investido e reiniciar o ciclo produtivo. Quem o fizer rapidamente terá condições para tornar-se o mais forte" (p. 62-63). Seguindo o mesmo raciocínio, o autor afirma que o espaço de consumo é determinado não apenas pelo poder aquisitivo de quem consome, "mas também pela acessibilidade do bem ou do serviço demandado" (p. 63-64).

A resposta para essa precariedade pode estar na própria estrutura dominante das indústrias culturais apresentada na seção 2.1. Não há, no DF, nenhuma grande empresa do ramo musical da indústria cultural. Existem apenas pequenas empresas de produção independente, empresas-franja. Ou seja, como já foi visto, as pequenas empresas não conseguem ter o controle sobre as etapas de difusão e distribuição porque estas demandam um altíssimo capital. Sem estratégia comercial voltada para essas duas etapas, as massas produzidas não se transformam em fluxos. Em todos os questionários aplicados, os músicos afirmaram que as principais formas de divulgação dos seus trabalhos são o contato direto com o público, o chamado "boca a boca", e/ou os sítios na rede mundial de computadores. 
Ademais, o fato de os próprios músicos venderem seus discos demonstra uma precariedade ainda maior, pois, dessa forma, seus trabalhos, dificilmente, terão penetração em um mercado maior do que o seu círculo de amigos, o que dificulta muito a conquista de novos admiradores. Alguns deles, os que têm produtor ou contrato assinado com alguma empresa, conseguem colocar seus discos à venda na Internet. Esta, porém, embora seja, de fato, um excelente veículo de difusão de informação, é ainda restrita a algumas faixas da população, o que torna a informação também concentrada nesses grupos que têm acesso a ela.

A consequência disso é que os músicos de Brasília criam uma rede de relacionamento entre eles para não somente ampliar as suas áreas de atuação, como também cooperar uns com os outros pela própria sobrevivência no meio. Todos os entrevistados disseram ter uma boa relação com outros músicos do DF e que todos colaboram com os trabalhos uns dos outros. Com exceção dos que são produzidos por alguém, são eles mesmos que marcam (e, muitas vezes, organizam) os shows, que convidam os músicos e/ou as bandas para se apresentarem juntos, que ajudam a divulgar e vender os discos uns dos outros, o que evidencia a solidariedade entre os músicos de Brasília e a falta de produtores e empresários para agenciá-los. O resultado é que os músicos daqui são levados pelas circunstâncias, não raro, a firmar contratos com empresas de outros estados (ou, em alguns casos mais isolados, fora do país) para garantir que seus trabalhos sejam divulgados, distribuídos e vendidos de maneira mais eficaz e efetiva.

Esses talvez sejam os pontos-chave para entender a dinâmica espacial da música em Brasília. Se essa Unidade da Federação apresenta altos indicadores de renda e escolaridade, pode-se supor que haja um grande mercado consumidor de cultura em potencial. No entanto, ao que parece, os meios de acesso aos bens de consumo ligados à música não são muito bem definidos. Por outro lado, se o espaço de circulação é ineficiente, como sugerem os resultados obtidos com os questionários, dificilmente, os músicos têm um retorno do que foi investido por eles - porque as gravações dos discos e as produções dos shows são quase sempre independentes e, por isso mesmo, realizadas com recursos dos próprios músicos; por conseguinte, não lhes é fácil obter capital para futuras gravações e shows. A isso se soma a já evidenciada falta de produtores tanto de shows como de artistas.

Os problemas ressaltados podem significar que Brasília é um ótimo espaço de formação de músicos, mas não para a produção de bens e serviços culturais, visto que a 
maioria dos entrevistados classificou o mercado local como "regular" ou "ruim", pois encontra alguns obstáculos à realização de seu trabalho. A reversão desse quadro depende de algumas mudanças na estrutura espacial brasiliense. 


\section{PROPOSTA PARA DINAMIZAR A CADEIA PRODUTIVA DA MÚSICA NO DISTRITO FEDERAL}

Após uma análise do que foi visto nos resultados da pesquisa qualitativa, cabe indagar qual é o "peso" da indústria cultural no espaço brasiliense. Tolila (2007) alerta que é preciso ter cautela na reflexão econômica ao se pensar no impacto que a cultura pode ter no desenvolvimento econômico. Caso contrário, tal reflexão, quando apoiada em uma abordagem restrita aos impactos, pode levar, apenas, a um emaranhado de números que reduz o fenômeno que é cultural e espacial a uma interpretação “demasiadamente mecanicista” dele (p. 74).

Utilizar-se de modelos econômicos para fazer uma análise espacial nem sempre pode levar a um resultado aproximado da realidade, pois, como adverte Santos (1979),

A distinção frequentemente feita entre espaço abstrato ou econômico e o espaço concreto ou geográfico - sendo este o espaço de todos - não permite que todos os elementos que entram na definição de um dado ponto no espaço sejam claramente captados e evita a identificação da hierarquia de forças que atuam sobre o espaço. [...] A dicotomia entre espaço geográfico e espaço econômico, apresentada como uma limitação metodológica, na realidade constituiu muito mais um obstáculo à análise espacial (p. 136-137).

Ora, um modelo, qualquer que seja, como o próprio nome sugere, é apenas um referencial de comparação com a realidade, um referencial de análise. Sua função não é, necessariamente, levar a uma aplicação imediata e total. No entanto, eles são importantes ferramentas para o tipo de análise pretendido neste trabalho.

Tolila (2007) aponta, então, algumas "pistas alternativas para a reflexão econômica" (p. 74) da indústria cultural ${ }^{15}$ :

a) Destacar o papel de certos setores econômicos na medida em que eles servem de vetores privilegiados para as relações entre as atividades culturais e o conjunto da economia: é o caso do turismo, da restauração do patrimônio [...] Encontra-se ali o que se pode chamar de "valor de atividade" das artes e da cultura;

b) Perguntar-se acerca do papel dos grandes equipamentos estruturadores de atividades culturais, acerca da importância

\footnotetext{
${ }^{15}$ Independentemente da abordagem escolhida, é importante ressaltar, como fez Tolila, que os resultados obtidos na análise são contribuições não apenas para a reflexão econômica, mas para um debate mais amplo, um debate democrático geral sobre cultura. E essa é uma das pretensões deste trabalho.
} 
econômica e territorial da constituição de "polos" de atração [...] que constituem zonas identificáveis de excelência onde a integração das diversas atividades é forte, verdadeiros distritos industriais;

c) Reinserir a cultura nos setores em crescimento pronunciado e/ou fortes criadores de empregos, no cerne do desenvolvimento econômico (p. 74, grifos meus).

O autor mostra ainda, dando como exemplo o que ocorre na França, como a eficácia nos gastos com cultura permite "valorizar a atração turística da cultura e do patrimônio", engendrar "uma série de consequências benéficas para a economia e o desenvolvimento local", estabelecer "relações estreitas com a oferta privada e o consumo do mercado cultural" e como "os créditos do Ministério da Cultura exercem um efeito de alavanca sobre os gastos culturais das coletividades territoriais" (p. 75-79), entre muitos outros desdobramentos positivos que o investimento público e privado em cultura pode trazer.

Apoiando-se, principalmente, nas duas últimas pistas apontadas por Tolila, pode-se, então, pensar que a cadeia produtiva do ramo da música pode vir a se constituir, analogamente a outros setores industriais, um polo de crescimento nos moldes da teoria de François Perroux.

Perroux (apud Schwartzman, 1977, p. 139) afirma que "o crescimento não surge em todo lugar ao mesmo tempo; ele se transmite através de diversos canais e com efeitos finais variáveis para o conjunto da economia”. Isso quer dizer que o crescimento é localizado, é desequilibrado e que a interdependência técnica é determinante na transmissão do crescimento. É quase que consenso entre os estudiosos da economia regional e da geografia regional que a polarização espacial é algo quase que inevitável ${ }^{16}$.

O crescimento ocorre de forma difusa, variável, dependendo sempre das características espaciais locais. Ele se manifesta "em pontos ou polos de crescimento, com intensidades variáveis, expande-se por diversos canais e com efeitos finais variáveis sobre toda a economia" (ibid., p. 146). Portanto, Perroux define esses polos de crescimento a partir da observação das estratégias de crescimento econômico adotada pelos países em desenvolvimento.

Perroux discorre sobre os polos de crescimento dividindo-os em três partes:

\footnotetext{
${ }^{16}$ A esse respeito, Schwartzman (1977) adverte que o conceito de polos de crescimento, por questões metodológicas, ainda não é suficiente para orientar uma política pública.
} 


\section{Indústria motriz e crescimento}

Uma indústria pode ser considerada motriz quando apresenta algumas características, tais como: "separação dos fatores de produção, concentração dos capitais sob um mesmo poder, decomposição técnica das tarefas e mecanização" (ibid., p. 147). Quando iniciam suas atividades, tais indústrias apresentam taxas de crescimento de seus produtos maiores do que a própria taxa de crescimento geral das indústrias e da economia nacional. Depois desse período, a procura do produto se torna mais elástica e a especulação (caso tenha havido) diminui ou acaba ${ }^{17}$.

Uma indústria motriz maximiza seus lucros a partir de suas próprias ações, de suas próprias estratégias de venda. A única relação que ela estabelece com as outras indústrias é a relação de preço - em um regime de concorrência perfeita. Caso contrário, uma firma passa a depender não só de suas vendas como também das vendas de suas concorrentes para maximizar seus lucros.

Essa relação pode levar a duas consequências:

a) mostra como se pode fazer a expansão (a curto prazo) e o crescimento (a longo prazo) de grandes conjuntos de firmas; b) põe em evidência, também, a diferença entre o investimento cujo volume e cuja natureza são decididos segundo a rentabilidade obtida pela única firma que investe e o investimento cujo volume e cuja natureza são ou seriam decididos tendo em conta os lucros e outras vantagens induzidas (ibid., p. 149).

Se todos os fatores que podem atravancar o crescimento de uma indústria não se realizarem na criação de uma indústria motriz, a produção desta poderá contribuir com o aumento líquido do produto global da economia. Caso algum deles ocorra, o cálculo do crescimento líquido terá de incluir as perdas de produtividade.

$\mathrm{O}$ autor ainda enfatiza que

A inovação bem-sucedida, graças a alguns agentes, constitui exemplo para outros e suscita imitações, que são elas próprias criativas. Enfim, a inovação feliz, ao suscitar um acréscimo de desigualdades entre agentes, conscientes, uns e outros, de suas atividades e dos resultados dessas atividades, intensifica a vontade destes, de ganhos e de poderio relativos. Como todo equilíbrio econômico dinâmico liga-se a um

\footnotetext{
${ }^{17}$ Esse raciocínio, embora apresentado para a indústria, pode ser aplicado diretamente a empresas ou a grupos de empresas, ressalva o próprio Perroux.
} 
equilíbrio social dinâmico, uma acumulação de abalos no primeiro repercute no segundo (ibid., p. 151).

\section{Complexo de indústrias e crescimento}

Um complexo de indústrias é caracterizado por três aspectos: a) presença de uma indústria-chave; b) regime não concorrencial no complexo; c) aglomeração territorial.

a) A indústria motriz pode aumentar suas vendas para utilizar plenamente, e do melhor modo, os seus capitais fixos [...]. Tal indústria, quando atinge seu nível ótimo de vendas, e desde que não seja monopolista, mantendo seus preços, pode proceder a novos abatimentos nos preços os quais induzem novos acréscimos no volume de vendas das indústrias movidas (p. 152).

A indústria-chave é a que impulsiona o crescimento industrial de maneira global, ou seja, em nível de economia nacional. Porém, para se classificar uma indústria, qualquer que seja, como indústria-chave, é preciso fazê-lo levando-se em conta todo o complexo formado por indústrias motriz e movidas.

b) Frequentemente, o regime do complexo industrial é, por si mesmo, "desestabilizante", por ser uma combinação de formas oligopólicas (sic).

Neste caso, as empresas mais fortes promovem acordos entre elas e com as empresas menores a fim de tornar o mercado não prejudicial para nenhuma delas, pois

esses regimes industriais não revelam, por si mesmos, a instabilidade de um complexo industrial, no qual cada indústria é parte do regime oligopolístico e no qual as indústrias são fornecedoras e clientes umas das outras (ibid., p. 153).

Por fim,

é a resultante dessas forças que provoca a expansão e o crescimento dos conjuntos de indústrias movidas" (ibid., p. 154).

c) Em um polo industrial complexo, geograficamente aglomerado e em crescimento, registram-se efeitos de intensificação das atividades econômicas devido à proximidade e aos contatos humanos (ibid.). É de fato a espacialização desse complexo de indústrias, à qual não só interessam a sua localização e a sua dinâmica enquanto complexo 
industrial, mas também a sua relação com os consumidores e com os demais agentes espaciais ${ }^{18}$.

\section{Crescimento dos polos e das economias nacionais}

Perroux destaca que "a economia nacional não mais se apresenta, unicamente, como um território politicamente organizado sobre o qual vive uma população, nem como um aprovisionamento de fatores de produção, cuja mobilidade cessa nas fronteiras" (ibid., p. 155). Ao afirmar que a economia nacional se apresenta como "uma combinação de conjuntos relativamente ativos (indústrias motrizes [...]) e de conjuntos relativamente passivos (indústrias movidas [...])" (ibid.), ele entende que a dinâmica da economia sobre o território coincide com a dinâmica espacial. Enfatiza, também, que são as indústrias motrizes que garantem às indústrias movidas os "fenômenos do crescimento" e destaca algumas "consequências fundamentais para a análise do crescimento econômico", como "o conflito entre os espaços econômicos das grandes unidades econômicas (firmas, indústrias, polos) e os espaços politicamente organizados dos Estados nacionais", e a existência de "políticas nacionais e nacionalistas em um mundo em que são sobrepujadas pela técnica e pelo desdobramento da vida econômica, subsistirão dissipações, que constituem, mesmo na ausência de conflitos violentos, entraves ao crescimento" (ibid.)

Pode-se entender, então, que tais indústrias motrizes, no ramo musical da indústria cultural, são as que Tolila chama de majors, pois, como exposto anteriormente, elas dominam (quase sempre de forma positiva) o mercado musical e polarizam outras pequenas empresas a fazerem parte do mesmo processo produtivo, só que deixando sempre os maiores riscos para as empresas menores. Da mesma maneira, pode-se dizer que as chamadas empresas-franja se assemelham às indústrias movidas.

Nesse sentido, cabe fazer uma adaptação do circuito de produção da música com a teoria formulada por Perroux. No entanto, é importante ressaltar que tudo isso ocorre de maneira ainda mais plena quando há, de fato, um investimento público em cultura. $\mathrm{O}$ próprio autor destaca a relevância do Estado na constituição desses complexos industriais.

\footnotetext{
18 No entanto, vale frisar que as mudanças técnicas e/ou políticas e a própria dinâmica da economia mundial como um todo podem favorecer ou levar à ruína um ou mais polos de crescimento, mesmo que bem estruturados espacialmente.
} 
No caso específico do DF, o que ocorre é que existem algumas "empresas movidas", mas não existe uma "empresa motriz"; há um espaço de produção e um de consumo, sem que haja um espaço de circulação. A saída para esse entrave pode estar na criação, em Brasília, de um complexo de empresas do ramo musical que sejam concentradas espacialmente, de forma a terem condições de se configurar como um polo de crescimento como propõe Perroux. Para isso, é necessário não só uma reorganização dos agentes espaciais que já existem, como também a inserção de novos agentes.

No Plano Piloto se localizam os três principais centros de formação profissional de músicos do DF, assim como alguns dos principais espaços onde acontecem shows e os mais relevantes estúdios de gravação e produção de discos. Dessa forma, dinamizar o mercado musical no DF depende, fundamentalmente, de desenvolver adequadamente a segunda e a quarta fases da cadeia produtiva da música. É necessário aprimorar a produção de artistas e de shows, pois a produção é a ponte que liga as primeiras às últimas fases da cadeia produtiva.

A cooperação mútua que existe entre os músicos de Brasília já cria uma atmosfera que favorece a concepção desse polo de crescimento. O que falta é uma organização espacial que permita que esse alto nível de profissionalização dos músicos e essa atmosfera de cooperação entre eles se convertam em produtos culturais a serem distribuídos e consumidos de forma plena. 


\section{CONSIDERAÇÕES FINAIS}

Diante do que foi exposto, veem-se claramente os aspectos que tornam a cadeia produtiva de música do DF ineficiente. Na RA I, que foi analisada, tendo-se em vista o fato de que as principais atividades econômicas são ligadas ao comércio e aos serviços, pode-se supor que o crescimento do setor musical traria enormes benefícios para a cidade. No entanto, pelas características espaciais e pela falta de infraestrutura adequada, o grau de desenvolvimento do setor está aquém das potencialidades que a cidade oferece.

Além da proposta de organizar o espaço musical brasiliense como um polo de crescimento, faz-se necessário chamar a atenção das autoridades governamentais para as muitas consequências positivas que o investimento em cultura pode gerar não somente para a cidade, mas também para seus cidadãos.

No caso específico de Brasília, onde a questão da ocupação territorial é complexa, uma indústria de baixo impacto industrial, que não necessita ocupar grandes áreas e que obtém altos lucros poderia ser uma alternativa viável para dinamizar a economia local. Mas dinamizar a economia local significa investir na atividade econômica, não em transformar o espaço urbano em mercadoria. A partir das deficiências apontadas pela pesquisa, é possível inferir que há no DF uma tendência de se investir em cultura apenas como chamariz de novos investimentos e para inserir a cidade em uma lógica de mercantilização do espaço urbano, o que, do ponto de vista geográfico, pode se revelar uma visão equivocada.

Se, para o governo, o que determina o investimento ou não do capital público é o retorno que esse investimento gera, a música se mostra, então, um excelente "negócio", pois pode impulsionar o crescimento da economia local. Nesse sentido, seria preciso repensar o papel que a arte e o artista desempenham na sociedade, para que eles sejam vistos como "engrenagens de uma grande indústria". Mas não foi esse o intuito deste estudo. A arte e os artistas não apenas contribuem para o crescimento da economia, como também são agentes fundamentais na construção da identidade e da cultura nacionais. Por outro lado, os artistas não podem ser vistos - como, aliás, é bastante comum - como pessoas que estão à margem da sociedade, pois eles são trabalhadores como outros quaisquer. Portanto, dinamizar o mercado musical brasiliense é também 
garantir que a classe artística tenha melhores condições profissionais e que o resultado do seu trabalho seja devidamente reconhecido e valorizado.

A qualidade da formação profissional que a cidade de Brasília oferece para os músicos não pode ser negligenciada. $O$ que este trabalho pretende suscitar é uma transformação espacial na/da cidade em prol da valorização da arte e da cultura e do desenvolvimento econômico por meio do investimento em música. 


\section{REFERÊNCIAS}

ÁlVAREZ, Gabriel O. (Org). Indústrias culturais no Mercosul. Brasília: Instituto Brasileiro de Relações Internacionais, 2003.

BOLAÑO, César. Indústria cultural: informação e capitalismo. São Paulo: Hucitec/Polis, 2000.

BRANT, Leonardo. Mercado cultural: panorama crítico e guia prático para gestão e captação de recursos. $4^{\mathrm{a}}$ ed. São Paulo: Escrituras, 2004.

LARAIA, Roque de Barros. Cultura: um conceito antropológico. $18^{\mathrm{a}}$ ed. Rio de Janeiro: Zahar, 2005.

NEVES, José Luis (1996). Pesquisa qualitativa: características, usos e possibilidades. Disponível em: <http://www.ead.fea.usp.br/cad-pesq/arquivos/C03-art06.pdf>. Acesso em: 24 jun. 2009.

SANTOS, Milton. A natureza do espaço: técnica e tempo, razão e emoção. $4^{\mathrm{a}}$ ed. São Paulo: Edusp, 2008.

. Economia espacial: críticas e alternativas. São Paulo: Hucitec, 1979.

. Espaço e método. São Paulo: Nobel, 1985.

SCHWARTZMAN, Jacques (Org.). Economia regional: textos escolhidos. Belo Horizonte: Cedeplar, 1977.

SEVERINO, Antônio J. Metodologia do trabalho científico. $22^{\mathrm{a}}$ ed. São Paulo: Cortez, 2002.

TOLILA, Paul. Cultura e economia. São Paulo: Iluminuras, 2007. 


\section{APÊNDICE A - Modelo de Questionário da Pesquisa Qualitativa}

\section{Análise espacial do mercado de música em Brasília}

Local:

Data:

$\underline{\text { Parte 1: Dados pessoais }}$

1. Nome completo:

2. Nome artístico:

3. Instrumento:

4. Naturalidade:

4.1. Para os de fora do Distrito Federal:

Por que veio para o DF?

5. Onde você mora?

6. Quais são os principais lugares onde você trabalha como músico?

- Escolas:

- Bares / Restaurantes / Pubs / Casas noturnas:

7. Qual é o valor mínimo do seu cachê? R\$

8. Qual é o valor da sua hora-aula particular? R\$

9. Qual é a sua renda mensal? R\$

10. A música é a sua principal fonte de renda?

( ) $\operatorname{Sim} \quad$ ( ) Não

10.1. Em caso afirmativo: essa renda é proveniente do ensino de música ou da realização de shows ou da gravação de discos?

11. Você tem algum outro trabalho não ligado à música?

( ) Sim. Qual?

( ) Não 
Parte 2: Sobre a formação musical e o mercado musical

1. Formação musical:

( ) CEP-EMB ( ) UnB ( ) Escola de Choro Raphael Rabello ( ) Autodidata

( ) Outros:

2. Você é músico solo ou toca em banda?

( ) Solo

( ) Banda-Qual(is):

( ) Free-lancer (sou músico contratado para trabalhos esporádicos específicos)

3. Qual(is) o(s) estilo(s) musical(is) que você mais toca?

4. Você (ou a sua banda) tem algum empresário e/ou produtor?

( ) $\operatorname{Sim} \quad$ ( ) Não

4.1. Em caso afirmativo:

4.1.1. Quem é o seu empresário e/ou produtor?

4.1.2. Qual o nome ou onde é a sede da produtora?

5. Como é feita a divulgação do seu trabalho?

( ) "Boca a boca"

( ) Panfletagem em bares/restaurantes, estúdios, escolas de música, etc.

( ) Sites/blogs na internet. Qual(is):

( ) Rádio

( ) Shows

( ) Por meio de outros músicos

( ) Outros:

6. Como é feita a captação de recursos para realizar o seu trabalho?

( ) Recursos próprios ( ) Patrocínio ( ) Projetos (FAC, Lei Rouanet, etc.)

( ) Outros:

7. Você já gravou algum disco?
( ) $\operatorname{Sim}, 1$ disco
( ) Sim, mais de 1 disco
( ) Não 
7.1. Para os que já gravaram:

7.1.1. Quando o (último) disco foi gravado?

7.1.2. Onde ele foi gravado?

( ) No DF ( ) Em outra cidade:

7.1.2.1. Se gravou no DF, em qual estúdio a gravação foi feita?

7.1.3. Quais destas etapas foram feitas no DF?

( ) Gravação e produção

( ) Prensagem

( ) Masterização

( ) Mixagem

( ) Arte gráfica

7.1.4. Quantas cópias foram feitas?

7.1.5. Quantas cópias foram vendidas?

7.1.6. Qual foi o gasto total com a gravação? R\$

7.1.7. Qual foi a fonte de recursos para a gravação?

( ) Recursos próprios - gravação independente

( ) Empresário / Patrocinador

( ) Projeto (FAC, Lei Rouanet, etc.)

( ) Outra:

7.1.8. Onde e/ou como o(s) disco(s) é(são) vendido(s)?

( ) O próprio músico vende (para o caso de você ter sido contratado como free-lancer)

( ) Eu mesmo vendo

( ) Alguma loja vende. Qual:

( ) É vendido pela Internet

( ) Outros:

8. Você costuma fazer shows no DF?

A. ( ) Sim B. ( ) Não, porque não faço shows C. ( ) Não, porque faço mais shows fora do DF 8.1. Caso tenha assinalado a alternativa " $\mathrm{C}$ ":

Por que você faz mais shows fora do DF?

9. Como é a sua relação com outros músicos do DF?

( ) Eu me dou muito bem com os outros músicos e eles colaboram com o meu trabalho

( ) Eu me dou bem com os outros músicos, mas essa relação não influencia diretamente no meu trabalho

( ) Não me dou muito bem com os outros músicos porque não estou completamente inserido no circuito musical local

( ) Não conheço muitos outros músicos do DF, pois me relaciono mais com músicos de fora 
10. Em sua opinião, o que é mais fácil e mais difícil fazer em Brasília? (Marcar "MF” para mais fácil, "F" para fácil e "D" para difícil)

( ) Dar aulas de música ( ) Gravar um disco ( ) Fazer shows

11. Em sua opinião, como está o mercado musical em Brasília?

( ) Ótimo - estou muito satisfeito com os resultados do meu trabalho

( ) Bom - tenho alcançado bons resultados com o meu trabalho

( ) Regular - tenho algumas dificuldades, mas tenho conseguido realizar meu trabalho

( ) Ruim - as dificuldades são maiores que os resultados

( ) Péssimo - não tenho alcançado bons resultados

12. Qual(is) é(são) a(s) maior(es) dificuldade(s) que você encontra para realizar o seu trabalho?

( ) Falta de público / alunos

( ) Falta de produtores (tanto de shows como de artistas)

( ) Problemas de divulgação

( ) Falta de estrutura para a realização de shows

( ) Falta de espaços para a realização de shows

( ) Problemas financeiros (não tenho dinheiro para gravar e/ou comprar equipamentos)

( ) Falta de estúdios de gravação

( ) Falta de investimento público em cultura

( ) Outros:

13. Comentários adicionais: 


\section{APÊNDICE B - Principais Escolas de Música e Locais de Show Apontados pela Pesquisa Qualitativa}

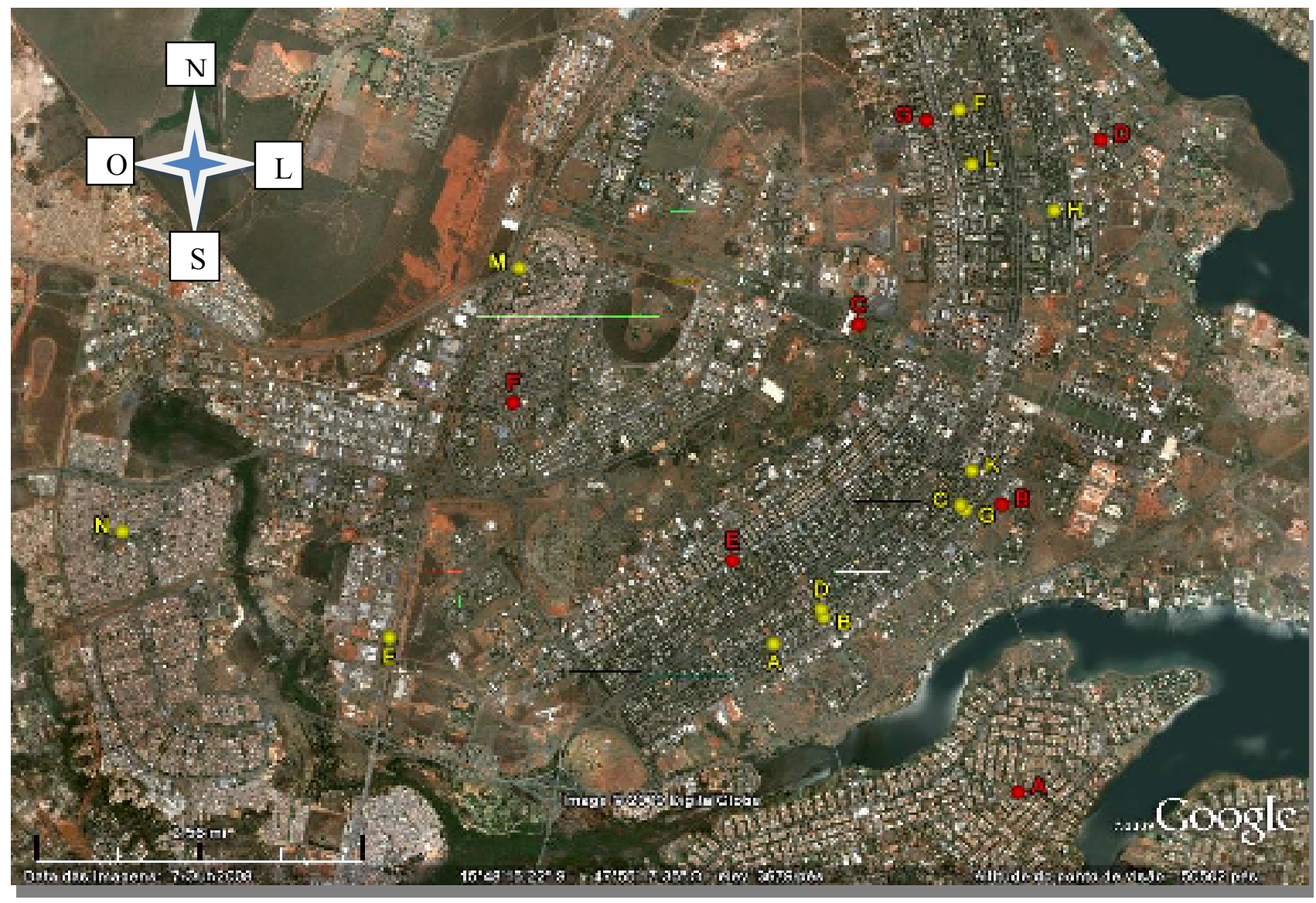

Legendas:

\section{ESCOLAS DE MÚSICA}

A - BsB MUSICAL (UNIDADE LAGO SUL)

B - CENTRo de EDUCAÇão PROFISSIONAL - ESCOLA DE Música DE BRASília

C - escola brasileira de choro Raphael rabello

D - DePartamento de música da UNIVERSIDAde de BRAsília (MUS/UnB)

e - gTr instituto de guitarRa - UNIDADE ASA NORTe

F-MASTER DRUMS

BARES / PUBS / CASAS NOTURNAS / RESTAURANTES
A - UK BRASIL PUB
H - FULÔ DO SERTÃo
B-O'RILLEY PUB
I-TANOOR
C-GATE'S PUB
J - VINHeIro são Vicente
D-C'EST SI BON
K - BAR BRAHMA
e - Di girotto
L - FeItIÇO MINEIRo
F-SCHLO $\beta$
M-CELVA
G-BOcANEGRA
N - LOUNGE PUB 